\title{
粉末接合現像に關す万研究(第一報) ${ }^{*}$ \\ 篩別せられた粉末群の粒度, 形狀比重, \\ 充填度等より見たる性格
}

京都帝大理學部化學教室金相學研究室

教授 理博 岩 瀨 慶 三

小川和彥

I）緒論

物のくつつをに關する研究は我々の日常生活に於ても或は亦種々の工業に於ても豐富に 見出されるが此の科學的の研究に闕しては斷片的には立派な研究も發表せられて居るが系 珫的に此を取扱纯んとする傾向岋近作のものである 著者等は此れに關聯して粉末冶金に 於ける粉末のくつつきの現象の解明に着手した，粉末金屬の燒結現象とは高度の分散狀態 にある粉末を或る形狀の型に充填壓縮成型し此孔を保護氣流中に於て加熱しくつつきを强 固ならしめる事である，粉末は壤樎により一鷹のくつつを(この度合を成型の尺度とする) を示めし更に加熱する事に依つてくつつきの强さ、を促進するのであるがくつつきとしては

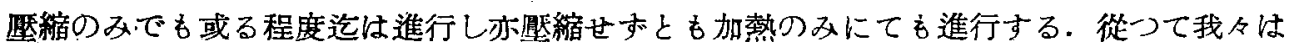
くつつきの現象を三つに分けて觀察して行く事にした・即ち

i) 壓縮無加熱のくつつき. 燒結とは言は䗑着と㭔ぶ.

ii) 加熱無嫄縮のくつつき，所謂る暁結現象に含まれる。

以上の分類化に依り介在する多數の條件を整理して焼結現象を比較的簡明化したのである が，此等に關して著者等が今日迄に得た實驗結果法昭和19年以後の日本金屬學界講演會に 於て發表して來た。その詳細に就ては逐次本誌に發表す石豫定である。

先つ粉末のくつつををとりあるる照合に考慮さる可きは使用粉末の外觀的性格粒度形狀 そ鸟分布狀態に就いてである，依て本報に於ては其等の點に關する篗察結果を述べる。

粉末形狀の觀察法粒度の箱別法(選別)に關しては現在迄に多くの報告があるが其等の力 法を個々單獨に取り上げたので屾複雜な立體的の粉末群の性筫を示し難い，從つて我々は

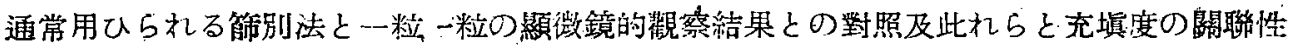
に就いて次の筫驗への足昜をつくるため本實驗を行つたのである.

* 京大理學部化學教室內金相學研究室

*本報告は昭和 19 年9月東京地方講演會に發表せるるの 


\section{II）實驗試料及び方法}

\section{A) 政驗試料}

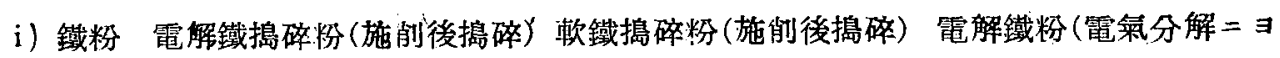
ルモ詳細ナル佟件不明)

ii) 電撯銀粉; (電氣分解) ·電流密度 $1 \sim 1.2 \mathrm{Ad} / \mathrm{cm} .{ }^{2}$ 硝酸銀溶液回轉陰極使用.

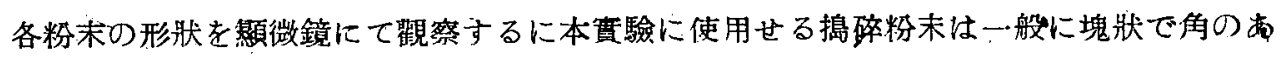
るる鎠い線を殘す。電解法に依るっのは杉葉狀を示す。

B) 實驗方法

i) 比重の測定これ惊一般法により Reischaner此重瓶を用ひた，此の場合水の溫度補

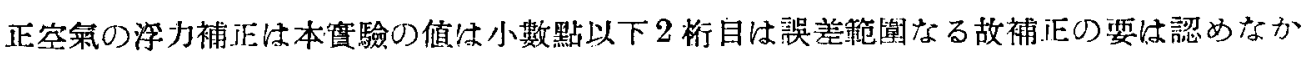
oた.

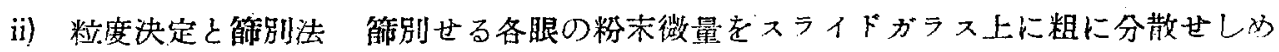
マイクロメーター對腿レーズにより其の大さを多數の粉末に就いて測定粒度分布統計多角 形を求めた. 此の昜合粉末は一般に不規則な形狀を有する故第 1 圖に示す如く比較的長を 部分（a）を標準に測定した：そして同時に略中央部でその線に直角に交实する部分の長さ （b）を讀み兩者の差又は比を以て粉末の形狀の平面的な不規則を統計的に現す樣に試みた。

iii）瓦斯放出量の測定 以上の筫驗に併行して粉末の表面積を間接的に測定するため各 節眼のものに就いて第2 圖の如き装置厄瓦斯放出量を測定した。郎ら容器 Cに一定量の粉

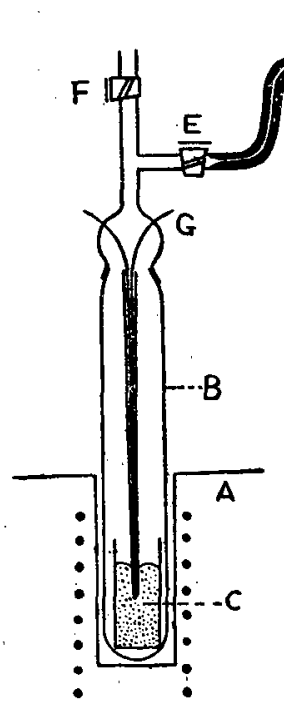

末文入扎常溫で充分排氣せるF 後のコックを

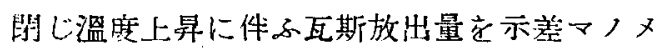
一ターD, 甭力恶で償んだ.

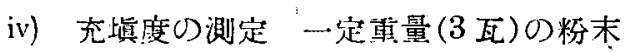
を測定简中に入れてその容積が略一定になる万 迄振洫して單位容積內の粉末の重量郎粉末群

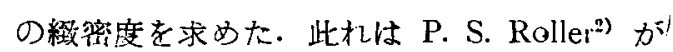
求めた充填度の逆數寺示す事にもなる。
$A=ク ロ \Delta$ 電気睢
B 透明巨英反広管
C. 試料
D 示差マフメーター
E.F.H. Јック
G 勃墰詨
K 熱要就保讙管

\section{III) 實驗結果}

i) 比重つ測定 電解鐵㨶碎粉末一 300 眼 及一-200 眼の比重測定結果は第 1 表の如大で 微粉では多量の管氣吸着曆の除土困難なるた め亦その㠜聚性により可成り低い值を示すか と豫想されてたが何れも略純鐵塊 $7.86\left(15^{\circ} \mathrm{C}\right)$ に 
单 1 表 電解鐵搗碎粉末の比重

\begin{tabular}{|c|c|c|}
\hline 探取粉末重量 $(-300)$ & 此 & 重 $\left(8^{\circ} \mathrm{C}\right)$ \\
\hline 0.491 & & 8.61 \\
\hline 1.026 & & 7.65 \\
\hline 2.803 & & 7.72 \\
\hline 5849 & & 7.82 \\
\hline 7.364 & & 7.76 \\
\hline 9.143 & & 7.71 \\
\hline 15.082 & & 7.78 \\
\hline 20.841 & & $7: 73$ \\
\hline 探取粉末重量 (-200) & 比 & 重 $\left(11^{\circ} \mathrm{C}\right)$. \\
\hline 1.612 & & 7.75 \\
\hline 2.412 & & 7.76 \\
\hline 5.379 & & 7.76 \\
\hline 7.529 & & $7.76 \quad 7.86$ \\
\hline 82.712 & & 7.77 \\
\hline 54.968 & & 7.72 \\
\hline
\end{tabular}

\begin{tabular}{|c|c|c|c|c|c|}
\hline & 種 & 類 & $\begin{array}{l}\text { 等取粉 } \\
\text { 末重量 }\end{array}$ & 比 & 䨌 \\
\hline \multicolumn{3}{|c|}{ 鱗片-狀鐵粉 (搗碎) (-300) } & 2.528 & 7.28 & $\left(8^{\circ} \mathrm{C}\right)$ \\
\hline & $\Rightarrow \quad(=$ & )$(-100)$ & 6.151 & 7.64 & $(ه)$ \\
\hline & 着 鐵 粉。 & $(-300)$ & 3.105 & 7.82 & $(\Leftrightarrow)$ \\
\hline & " & $(-100)$ & 5.205 & 7.67 & $(")$ \\
\hline \multirow{2}{*}{\multicolumn{2}{|c|}{$\begin{array}{c}\text { 霄解鐵捣碎粉 } \\
\text { " }\end{array}$}} & $(-300)$ & 5.849 & 7.82 & $(")$ \\
\hline & & $(=)$ & 7.364 & 7.76 & $(\geqslant)$ \\
\hline & 罣 銀 粉 & $(-300)$ & 1.940 & 7.8 & $\left(11^{\circ} \mathrm{C}\right)$ \\
\hline & " & $(-100)$ & 5.08 & 9.8 & $(\geqslant)$ \\
\hline
\end{tabular}

近い值を示した。これよ゚り粒度の大なる粉末では 向更比重は汇常に近い值を示す。

唯し粉末の探取量による結果の不同は前表にみ る如くその量 1 瓦以下の場合に汢注意して筫驗を 反覆するも不同を免机和誤差を生じた。次に電着

銀粉の場合は粒度によりその比重は相違し粒度の小なるものは可成り低い値を示す（第 2 表).以上の結果は兩粉末の吸着層表面狀態の差が明確に㨔まれねば結論は得られぬが笔着 銀粉は -300 眼にては凝聚性强く振盪するも分散が困難である岁搗碎鐵粉にはかかる傾向 が認められない，故に電着銀粉の場合は此の凝聚性により粉末間の氣泡を包含し見溎け體 積大となるため測定值小になるものと考へられる。

形狀と比重の潞係後に述へる好く淿碎鐵粉の形狀は一定せるものではなく亦電着粉末は 前述の如く杉集桨であるぶ此の形狀の差異は比重に餘り影響しない(第 2 表).

依比重の值は凝聚性を左右する粉末の粒度，表面狀況に影響される事が推測される。

ii）篩別の意味．篩別法は大まかにその大さを區別する手段と考へられて居るが次の點 を明確にする必要がある。郎ち節別された粉末群仕玱確に如何なる大さの分布狀洗にある かと言ふ點並びに平面的な笠眼に對して站體的な格末は都合良く此の眼を通るに過ぎない のであるから形狀が異る場会には必秘しも篂別によつて同じ大いさり粉末が分別されて居 るとは限らないが此の笠別法の不備なる點, 以上二つの點に就いて我々が認識する事が篩 別法の意味を知る事になるのである。

今電着銀粉末を 30 瓦つつ探取 $320,300,250,200,150$, 及 100 眼の篩ひによつて 20 分間 つつ節ひ分けて各群の粉末を溦量スライドガラス上に分散せしめ前述の方法で顯微鏡によ b個々の粉末の大さを測定しその多数の値から粒度分布統計多角形第 3 乃至 6 圆を得た.

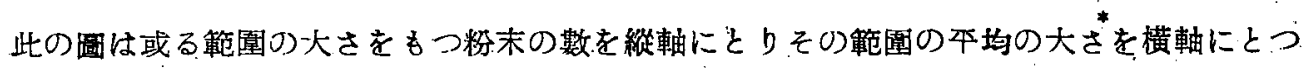

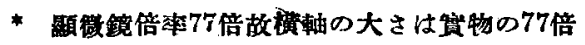



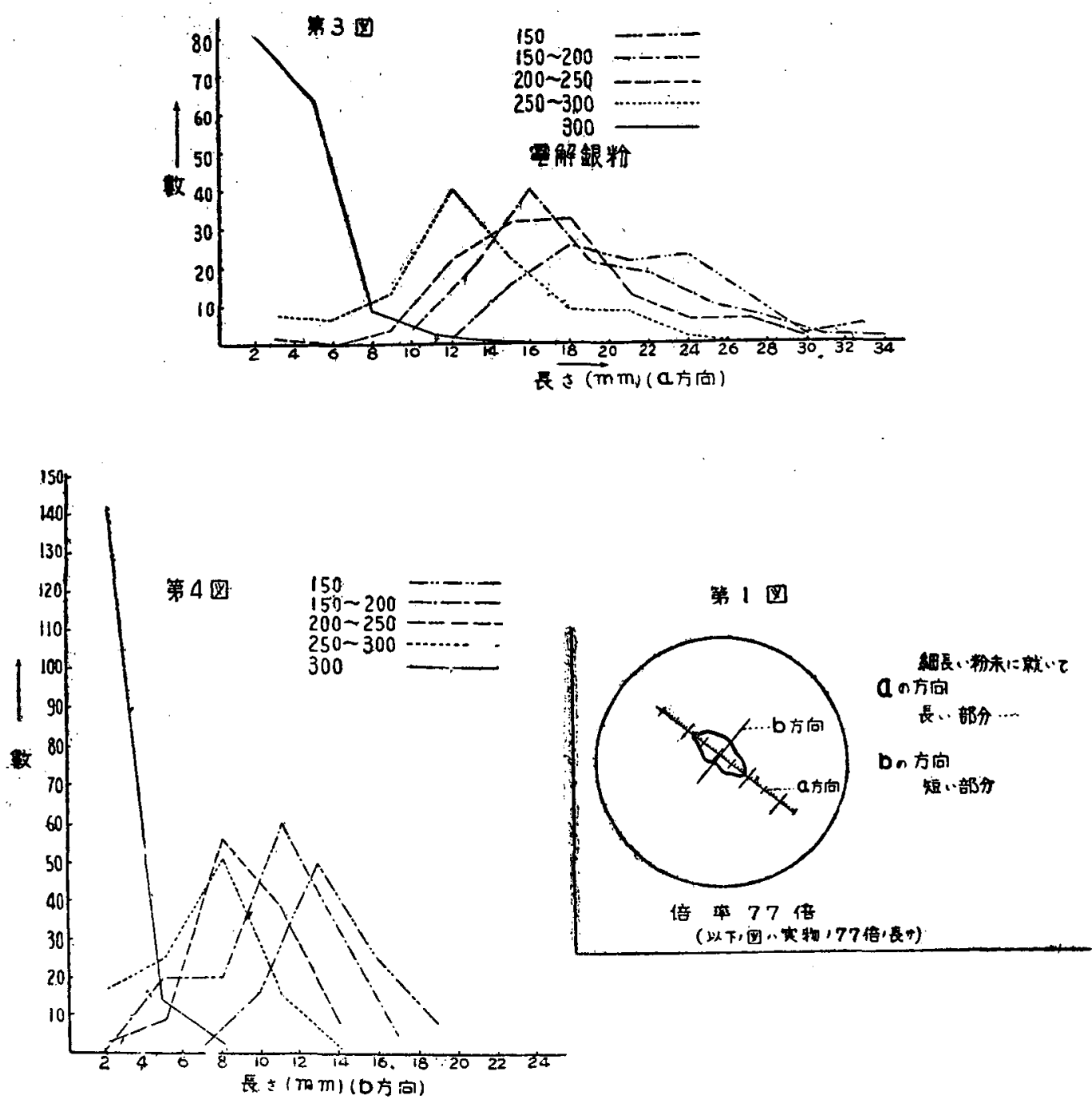

てある. 第 3 圖は前述の妨く粉末の比較的舆い方向の長さを測定せるもので第 4、圖は短い 部分第 5 圖はその兩者の比を示す故比が 1 ならば球形 1 より.大なら形狀の細長を事を示し て居る．上上 3 固の結果から－300眼のものは可成り粒度が揃つて居るが -250 ，及びそ れ以上の箱目で䇠別された粉末群は色々の人いさのものか可成り含まれて居り最も多い粉

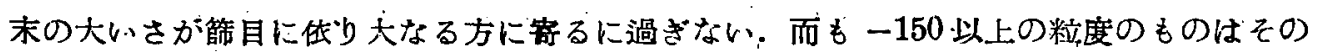
粒度範葍が更に著しくなつて居ら如何なる大いさの粉末が最す多いかも判らない，以上 -300'のものが此較的粒度の小なるもので揃つて居る事, 亦更に微粉末を含有して居る事 は粉末表面積の間接的測定か $5 る$ 制る。郎ち前迅の方法に位る各眼の一定量の粉末の瓦斯 故出量を求めたのが第6.㯖であるー300のものは他のものに比較して瓦斯放出量が著しく

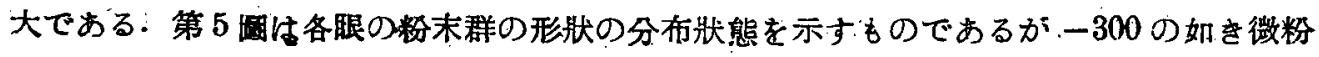



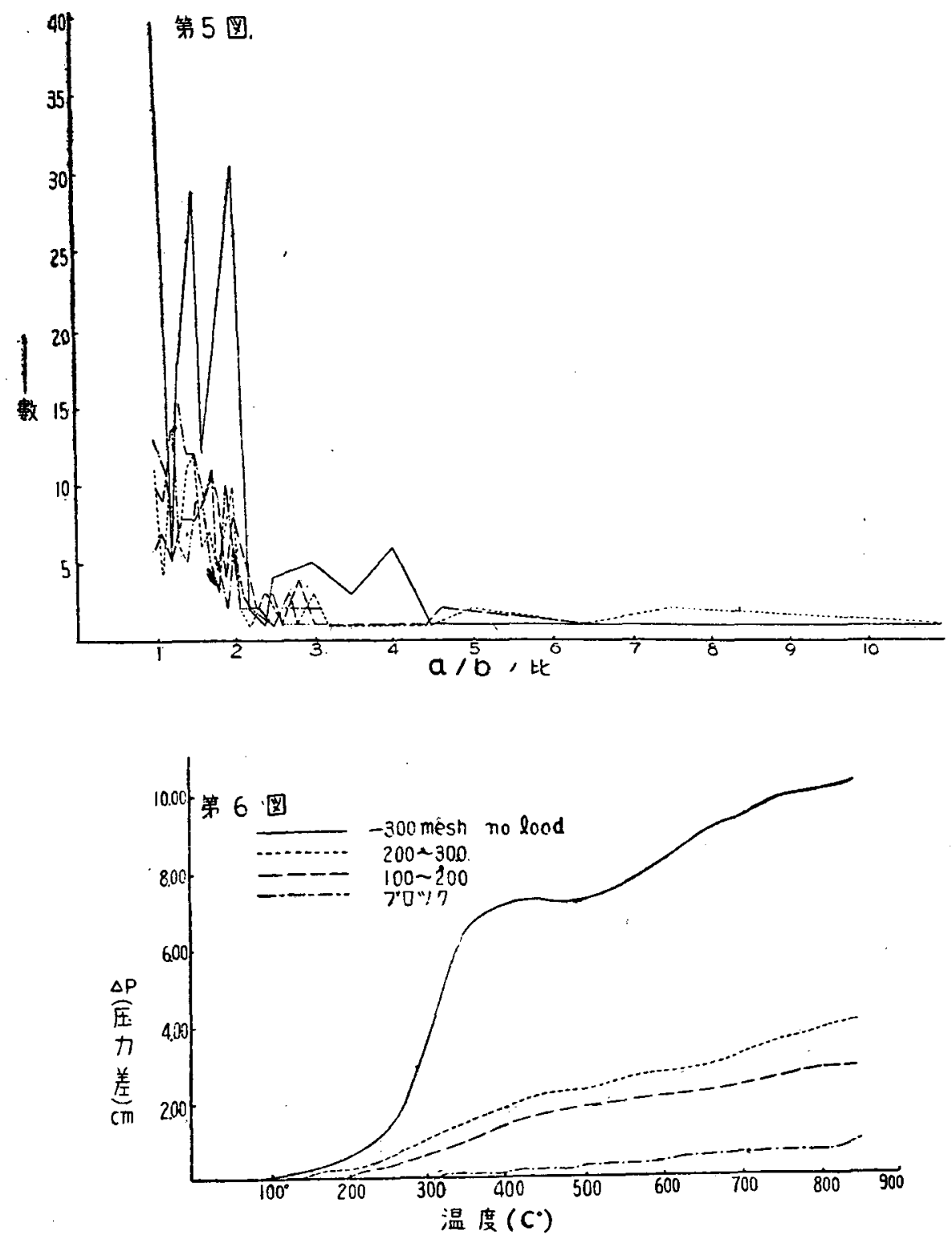

末に於ても比 1 上り大なるもの多く細長いものが可成り含まれて居る事が此の結果から判 る. 粒度の大なる粉末群も矢張り細長い粉末を同樣に多数含んで居る.

次に形狀の異る電着鐵粉，電解鐵，軟鐵搗碎粉，捣碎鱗片狀粉に就ての結果を第 7〜9. 圖に示す. 粒度灶何れも一300眼のものである圖に見る如く電解瞔軟鐵搗碎粉末の塊狀の るのは略々同じ傾向を示して居るが，此等と著しく形狀の異る電着鐵粉と鱗片狀搗碎粉末 とは稍々これ等と相違を示して居る. 而して此の形狀分布の差は第 9 圆のの比を横蟿にと る統計分布多角形により或る程度は知り得る。郎ち，電解鐵軟鐵摛碎粉末は球形に近促す。 

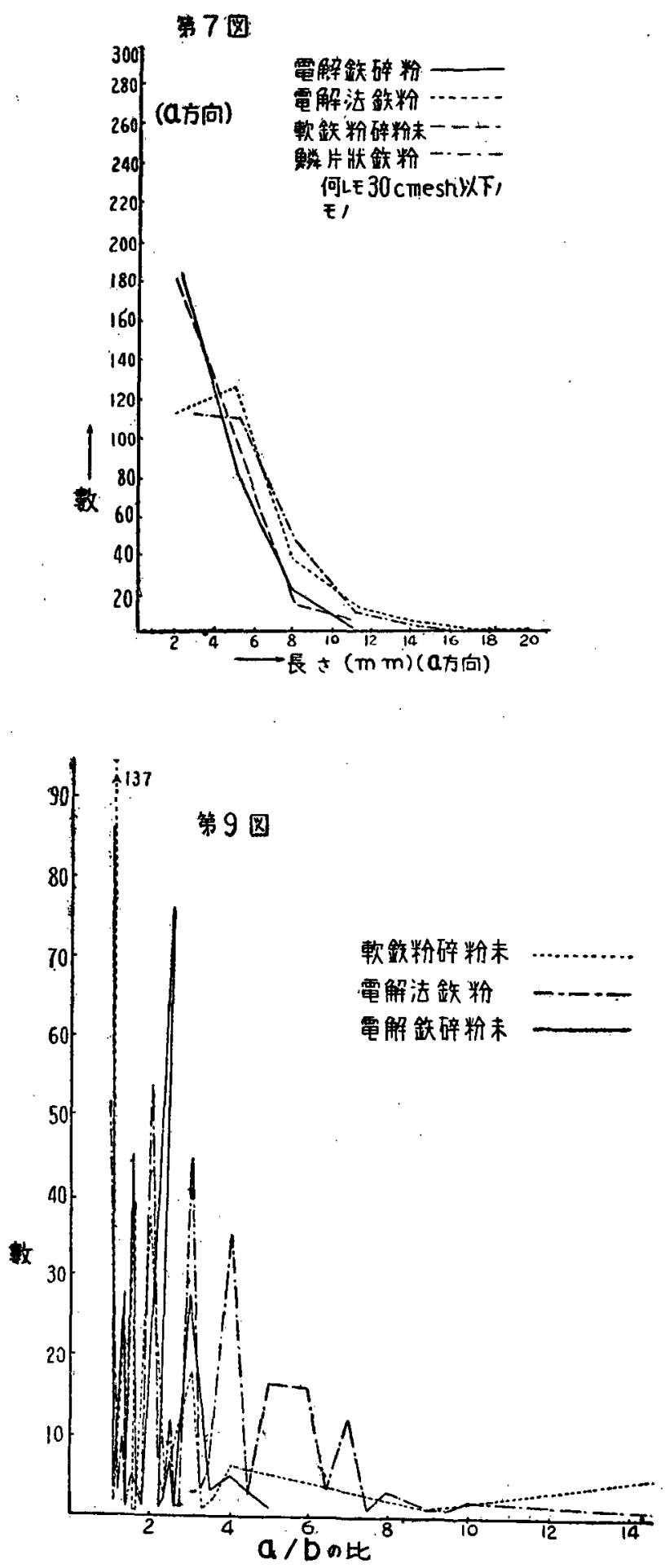

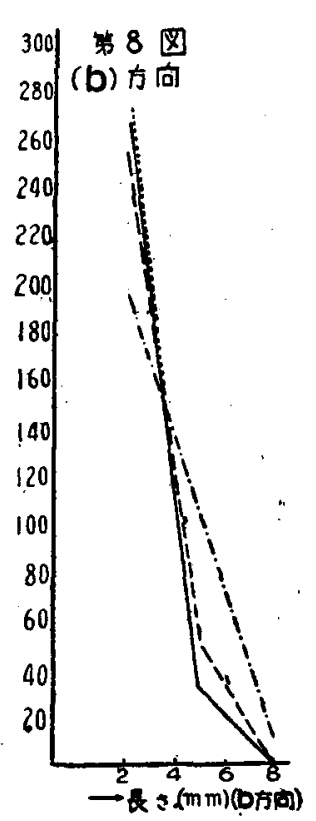

る゙ものが多いが電着鐵粉は 細長い粉条を多數含んで居 る事が判る，亦同じ搗碎粉 でち電解鐵の方が軟鐵のそ れより球形類似のものが多 くなつて居る。

以上要するに笠ひによつ て粉末を夫々或る大きの範 圈に區分した場合に同じ籍 を通つた粉末群の中には細 いものとしからざるまのと が夫々種々の制合に含まれ て居りその分布狀態は一樣 ではない依てー300の如き に於ては $-100 を-200 を$ の相造から考人て`-200と -300 に存在すると考へ 5 れる相違が必ずしる存在し

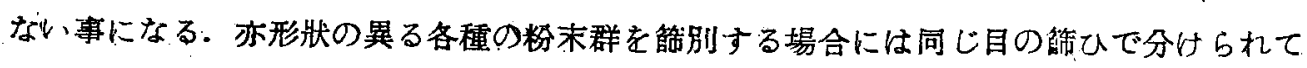


もその粒度分布狀態に差を示す．以上の事は顯微鏡に徒り多數の個々の粉末に就いてその 大いさを測定し分布統計を取る事により初めて知り得るのである。笠別せる粉末群を取扱 ふ場合に充填度成形難易等色々の現象を觀察する上に於て此等の點を考看に入れる必要が ある。

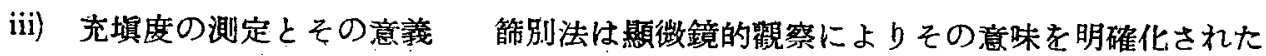
のであるが，顯微鏡的方法自體近體的な粉末を平面的に觀察すると言ふ點と測定技術上極 めて小さな微粉を見逃し易いと言ふ點に缺點がある。低て吾々が粉末群の性格を制断する 上に於て平面的な测定法である篩別法，顯微鏡的觀察の外に，粉末の立體性，大さの分布 牀態も同時に現れるる充填度 (粉末群の鐵密度)を併用する事がある。依て顯微鏡的觀察々充 媜度の關係から充填度自體の意昧を探つてるる.

製造履糜從つて形狀も異つた粉末群のー-300のものに就いて充填度を測定すれば第 3 表 の結果になる，電解鐵搗碎粉と軟鐵搗碎粉末とは第 7〜9圖に示す如く顯微鏡的觀察に於 ては粒度分布は略等しく形狀の分布も稍々少し異 つて居るが大體額似して居るのに充信度には大な る差が現れて居る。而るに電着鐵粉と軟鐵揚碎粉 は形狀に著しい相違があり粒这分布にも差がある

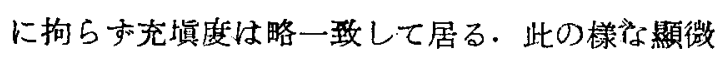
鏡的觀察により求められた粒度分布の狀態に認め られない差が充填度に大きぐ現れるのは如何なる

第 $\mathbf{3}$ 表 粉末の見脚け竅度

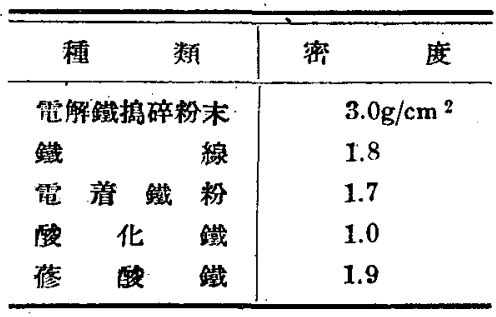

理由によるのであららか：充填度なるものは見掛けの密度を示するので一定の容積內に入 り得石質量であるから形大いさの分布が粒と粒との傹間をつめるのに都合の良いものが充 填度が大となる譯である。粉度分布を求のる場合には便宜上形狀を本面的に授算したが此 の場合には粉末の立體的な厚み，山凹等が問題になる．要するに年面的觀測では見逃され た點が集積して充填度に影響してくろ。

此等の點も考虑に入れて電解鐵軟鐵;

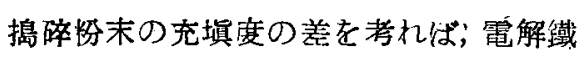
の軟鐵に比較して䀠性に富む點が搗碎 された個々の焙形その分布に充買度を 大ならしめる様な性格を與へて居る樣 に考へられる。第 9 圖に於ても軟鐵搗 碎粉は電解鐵搗碎粉上り稍細骎いもの が多い樣に考へられるが, 更に前者は後 者のものと比較して管狀の粉末が介在 少くその脆性のため極微粉の存在する

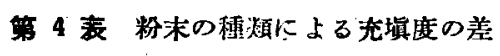

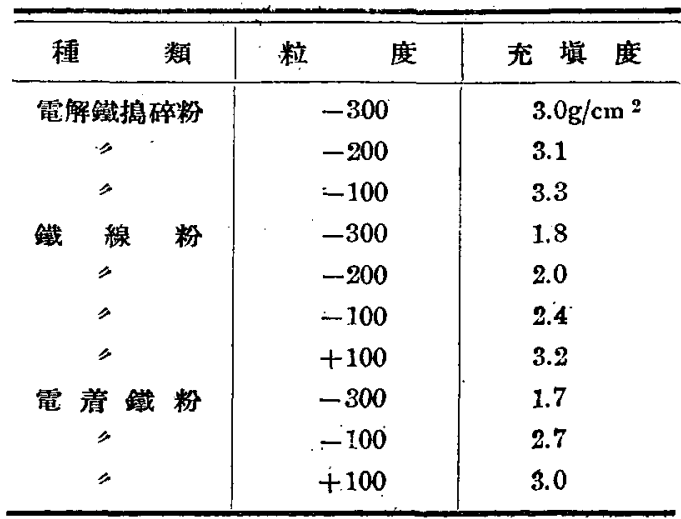


のが綿密に觀察すると判るが，此の點に關する詳細は後報に述へる，要するに此等の電解 鐵搗碎粉の形狀，大いさの分布が細長い盤狀粉より球形にして而もその鄚間を埋める樣な 徽粉の介在して完填度を高める分布狀態に接近して居る栐に推測出來る.

次に第 5 表に示す如く两者の粉末とも，粗粉になると克填度が大になつて居る此れは粒 度が大になれば嘹間の數が減つてくるのと，その㩐間を埋のるに都合の良い樣に粒度形狀 の分布に廣い幅がある爲め心樣に存へられる。

結論

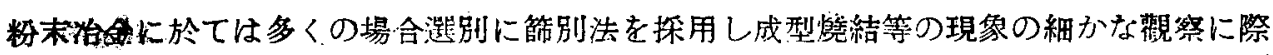
し. 同じ眼の粉末群は略同じ性格を備へて居るものし集合の如くに假定して考察を下し勝

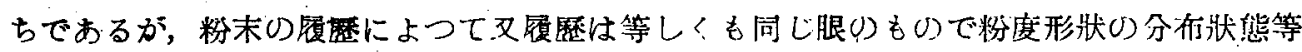
粉末の性格が異つて居る場合がある：又眼の相違が單なる粒度の相遙のみでなく形狀その

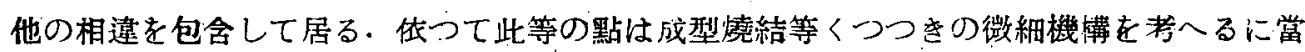
つて等閉視し得ないちのである故，先つ此重，粒度，形狀，その分布狀態充㙗度等上り見

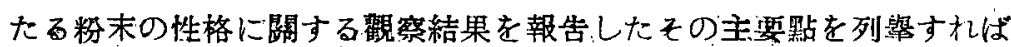

i) 各種の粉末の比重を此重瓶の一般法で測定し，鐵粉に就ては探取量 1 瓦以上の時は 粒度形狀の如何に關せす純鐵塊に近い值を示す事索知つた，微粉凝聚性に上る粉末比重測 定上の困難は貫驗試料の木さの程度で性現れなかつた。但電着銀粉はその程度の粒度で㠜 聚性を示し銀塊より可成り低い值を示した。

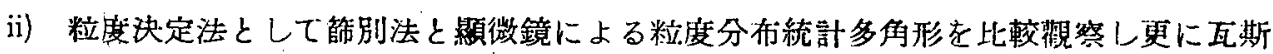

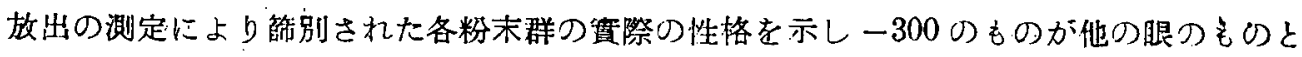

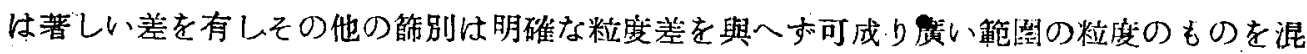
合する事を示した。

iii) 本面的な飾別法が立體的な形狀の異る粉末を篩ひ分けた場合に粓桨選別として如何 なる誤差を生するかを明らかにした，iii）粒度分布粒計多角形で同一の傾向をたどるもの に就ても，充填度の異る事實から前述の方法文では粉末の立能性を充分に表さない事を示 し粒度决定には飾別，in）粒度分布多角形と充填度を併用をる可を事を推測した。

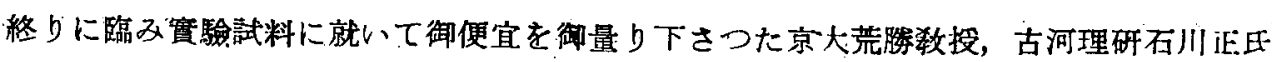

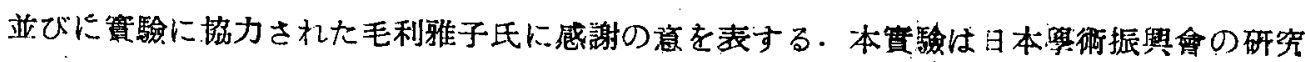
補助によるもので同會に給謝の意を表する。

i) P Skaupy. Metallkoramik, (1943)

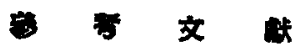

ii) P. 5 Roller; Ind. Eng. Chem. (1930) 22 1200 8 